\title{
Effect of Sitagliptin "a Dipeptidyl Peptidase-4 (DPP-4) Inhibitor" on the Endocrine Part of the Pancreas in Experimentally induced Diabetes in Adult Albino Rat; A Light Microscopic and Biochemical Studies \\ Tamer M. M. Abu-Amara and Zeinab M.Gebaly \\ Al-Azhar University- Histology Departments (Boys-Girls)
}

\begin{abstract}
:
Sitagliptin is highly selective dipeptidyl peptidase-4 (DPP-4) inhibitor that is considered as one of the new oral therapies for management of type II diabetes. Because of the sitagliptin unknown effects on the endocrine part of the pancreas, especially on the cellular levels, this study was done to evaluate its effect on the endocrine part of the pancreas in experimentally-induced type II diabetic in adult albino rats.
\end{abstract}

Material and Methods: The present study was carried out on 30 adult male albino rats which were divided into; Group I (untreated control group), Group II (diabetic group), where type II diabetes had been induced via alloxan intake) and group III (treated group), where $0.14 \mathrm{mg} / 100$ mg B.W. sitagliptin was given orally per day for 3 weeks after induction of type-2 diabetes.

The specimens were prepared for light microscopic examination. In parallel, the related biomedical parameters such as serum glucose and serum insulin levels had been estimated, statistically analyzed and compared between the three groups.

Results: Sections of pancreas taken from diabetic rats showed morphological changes in islets of Langerhans cells in the form of pyknotic nuclei, cytoplasmic vacuolation, poor differentiation and abnormal shape and size of the cells. These morphological changes had been partially recovered in diabetic rats treated with sitagliptin. Also, the hyperglycemia and hypoinsulinemia that was detected in the control diabetic group had been nearly returned to normal after sitagliptin treatment.

Conclusion: Sitagliptin drug has improved islet functions on both morphological and biomedical parameters in type II diabetic rats and can be taken into consideration as one of the new oral antidiabetic drugs on the human level that need to be more investigated.

Keywords: Sitagliptin, Type II Diabetes, Dipeptidyl Peptidase-4(DPP-4) inhibitors Albino rats, Alloxan.

\section{Introduction:}

Currently, there are various pharmaceutical drugs for the management of type 2 diabetes. According to the UKPDS study, most of the available oral therapies for diabetes fail with time. This failure is probably due to the progressive decline in beta cell function (UKPDS, 1998). On the other hand, most of these medications that are commonly used such as thiazolidinediones (TZDs), sulfonylureas, and insulin are associated with significant weight gain (UKPDS 1998). New therapies such as incretins may have an effective role in reducing hemoglobin A1c (HbA1c) through keeping beta cell functioning and without causing weight gain. Two groups are included in this class; 
incretin mimetics (Glucagon-like peptide (GLP-1) analogues such as Exenatide) and incretin enhancers (Dipeptidyl-peptidase four (DPP4) inhibitors, such as Sitagliptin) (Halimi, 2008).

$$
\text { Dipeptidyl Peptidase-4(DPP-4) }
$$

inhibitors work through inhibition of the DPP-4 enzyme that is responsible of degrading incretin hormones such as glucagon like peptide (GLP)-1 and glucosedependent insulinotropic polypeptide (GIP) (Mest and Mentlein 2005). Inhibition of DPP-4 enzyme stabilizes the intact or active form of the incretin hormones (Ahren andSchmitz 2004). Active GLP-1 and GIP stimulate glucose dependent insulin biosynthesis and release. Moreover, GLP-1 suppresses release of glucagon, delays stomach emptying, and increases satiety (Holst and Gromada 2004). In rodent, DPP4 inhibitors improved insulin secretion, glycemic control, and beta cell function (Ahren et al., 2000; Pospisilik et al., 2002; Reimer et al., 2002). In type 2 diabetic patients, treatment with DPP-4 inhibitors decreased postprandial glucose excursion, fasting plasma glucose (FPG), and HbAlc. Moreover, in relation to placebo, DPP-4 inhibitors have been shown to be well tolerated with neutral weight effects with low incidence of hypoglycemia and gastrointestinal adverse events (Ahren $\boldsymbol{e t}$ al., 2002; Ahren et al., 2004a; Ahren et al., 2004b).

Sitagliptin is highly selective DPP-4 inhibitor that can be used through oral route. In sitagliptin-treated rodents, plasma DPP-4 activity was inhibited (up to $80 \%$ ) and the active GLP-1 levels were elevated (up to 3 folds). Moreover, after an oral glucose tolerance test, glucose excursion showed nearly a maximal reduction (Kimet et al., 2005).

Furthermore, when single doses of sitagliptin (up to $600 \mathrm{mg}$ ) were given to healthy men, it was well tolerated and no hypoglycemia, weight gain or gastrointestinal problems had been detected (Herman et al., 2005; Brain et al., 2006). In addition, sitagliptin inhibits plasma DPP-4 enzyme activity and augments active GLP-1 levels in a dose dependent manner and its pharmacokinetic $(\mathrm{PK})$ profile is consistent with once-daily dose (Herman et al., 2005). Moreover, sitagliptin has been found to be effective and safe as an add-on therapy to insulin in reducing blood glucose levels in patients whose lack the ability of endogenous insulin secretion (Eiji., 2011).

From the above mentioned data, it seems that there is cumulative data that support the role of sitagliptin as one of considerable oral anti-diabetic drugs for management of type 2 diabetes. However, lacking of the studies, especially the histological studies on the cellular and molecular levels, considering sitagliptin effect on the endocrine part of the pancreas weaken this consideration. This work aimed to study the histological and biochemical changes that may occur in the endocrine part of the pancreas of alloxan-induced type II diabetic adult albino rats after treatment with sitagliptin. 


\section{Material \& Methods:}

This study was carried out on 30 adult male albino rats ranging in weight from 150 200 grams each. All animals were kept in clean ventilated cages under similar environmental conditions and were fed the same laboratory diet.

They were divided randomly into three equal groups; the first group "Group I" was considered as a Control group and did not undergo any intervention, while the second and third groups were subjected to induction of type II diabetes via single injection of alloxan $(120 \quad \mathrm{mg} / \mathrm{kg}) \quad$ intraperitoneally (Malaisse, 1982). The second group "Group II" was considered as a Diabetic Group where induction of diabetes was not followed by any further medical intervention, while the third group "Group III" was considered as a "Treated Group" where induction of diabetes was followed by treatment with sitagliptin $(0.14 / 100 \mathrm{mg} \mathrm{B.W.})$ orally for 21 days. The dose was calculated according to Paget and Barnes(1964).

\section{Parameters of the study:}

A) Microscopic study: Fresh sections from the pancreas of the three groups were prepared for paraffin sections, $6 \mathrm{~mm}$ thickness, and stained by heamtoxylin $(\mathrm{Hx})$ and eosin (E) stains(Clayden, 1971) and modified aldehyde fuchsin (Halami 1952). After that, the stained sections were examined via light microscope, photographed and all the detected variations between the three groups on the level of the microscopic findings had been scientifically discussed.
B) Biomedical and laboratory

findings: Collection of rats' blood serum was taken to estimate the following parameters:

1) Serum glucose level: Using enzymatic colorimetric method (Trinder, 1984).

2) Serum insulin level: According to the method used by (Reeves, 1983).

C) Statistical analysis: the obtained results were statistically evaluated and analyzed using SPSS-14 system.

\section{Results:}

\section{I-Microscopic examination:-}

\section{A- Control group (GI):-}

Examination of Hx\&E stained sections of pancreas from the control group, revealed normal appearance of the islets of Langerhans, they irregularly scattered within the exocrine pancreatic acini. The islet appeared as pale spheroid masses with rich vascular supply.

Each islet is formed of numerous cells with central spherical nuclei. Beta cells are the most abundant cells and occupy the core of the islets and contain numerous granules. Alpha and delta cells are observed at the periphery of the islets (Figs.1,2).

Sections stained with modifiedaldehyde fuchsin showed B-cells which were distributed all over the islet, while other cells were stained yellow and tend to be at the periphery of the islets (Figs. $3,4)$.

\section{B-Diabetic group (GII):-}

Examination of $\mathrm{Hx} \& \mathrm{E}$ stained sections, showed that the islets were irregular in outline and showed marked reduction in 
its size. The islet cells were poorly differentiated. Decreased isletscellularity was observed (Figs.5,6).Some islet cells showed marked degenerative changes and have very small pyknotic nuclei (Fig. 7). Also, marked vascular degenerative changes had been detected at the region of islet suggesting arteritis (Fig.8).

Section stained with modified aldehyde fuchsin showed that most of islet cells were affected. The cells showed cytoplasmic vacuolation, pyknosis and karyolysis of their nuclei (Figs.9,10).

\section{C- Sitagliptin treated group (GIII):-}

Examination of Hx\&E stained sections of the diabetic group which was treated by sitagliptin showed partial return to the normal cellular distribution in the islet of Langerhans and increased cellularity with ill differentiation of the different cell types (Figs.11\&12).

In modified aldehyde fuchsin stain sections of this group showed mild increase in the number of Beta cells and the islets appeared more organized with less vacuolated cells, but the cells were still poorly differentiated (Figs.13,14).

\section{II-Biochemical parameters:-}

Changes in the serum level of blood glucose and insulin are demonstrated in the following table and histograms which showed partial recovery of both levels to their values in the control group (Table 1 \&Histogram.1, 2, 3).A $\boldsymbol{P}<\mathbf{0 . 0 5}$ was taken indicate statistical significance. Results are reported as average $\pm \mathbf{S E}$. 


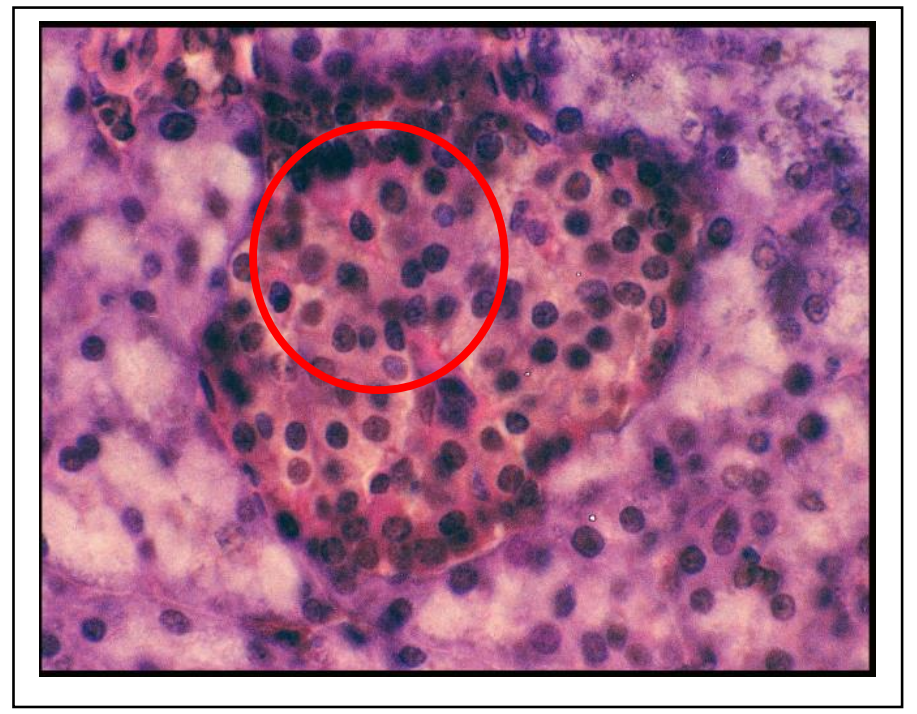

(Fig. 1) Photomicrograph of a control pancreas of adult albino rat showing the normal cellular distribution in the islet of Langerhans , normal pancreatic acini are distributed around the islet. (Hx.\&E. stain X 1100)

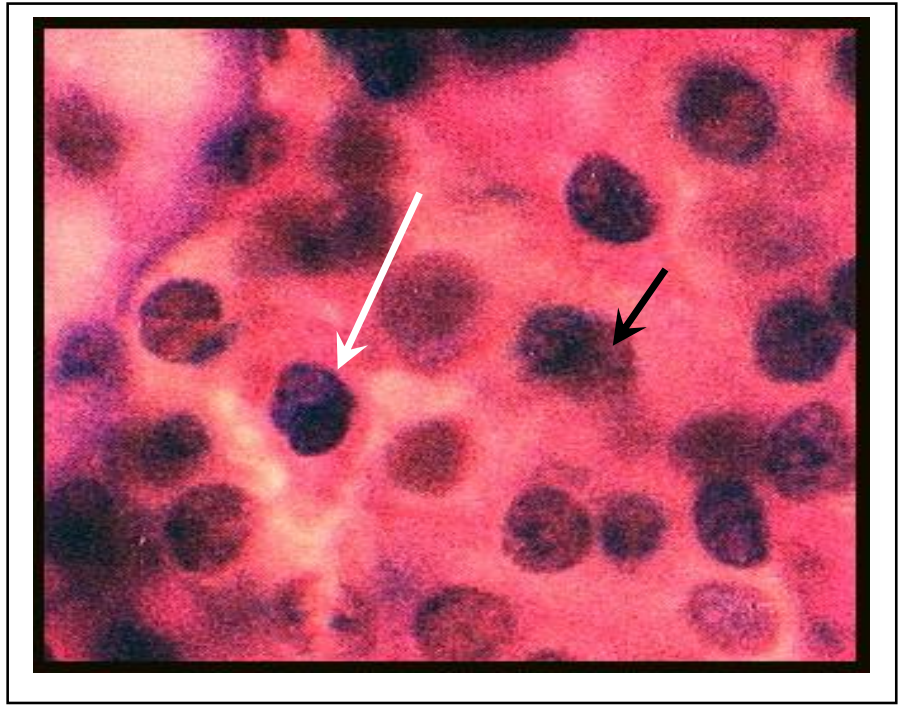

(Fig. 2) Photomicrograph of a control pancreas of adult albino rat showing the normal cellular distribution in the islet of Langerhans , the white arrow shows alpha cell while the black arrow shows the beta cell . (Hx.\&E. stain X 1400)

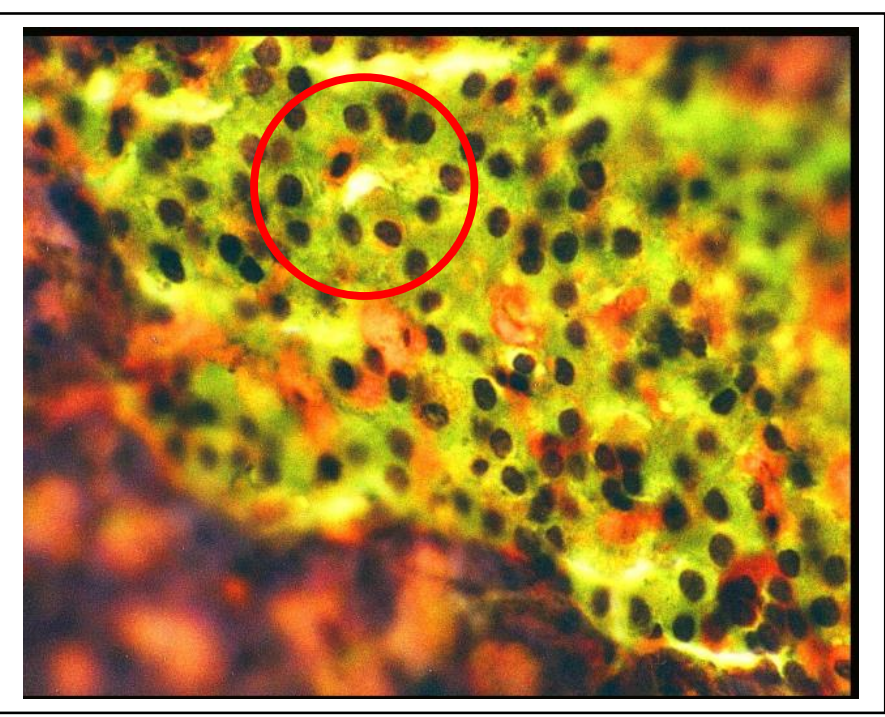

(Fig. 3) Photomicrograph of a control pancreas of adult albino rat showing the normal cellular distribution in the islet of Langerhans , normal pancreatic acini are distributed around the islet.

(Modified aldehyde fuchsin. stain X 1100)

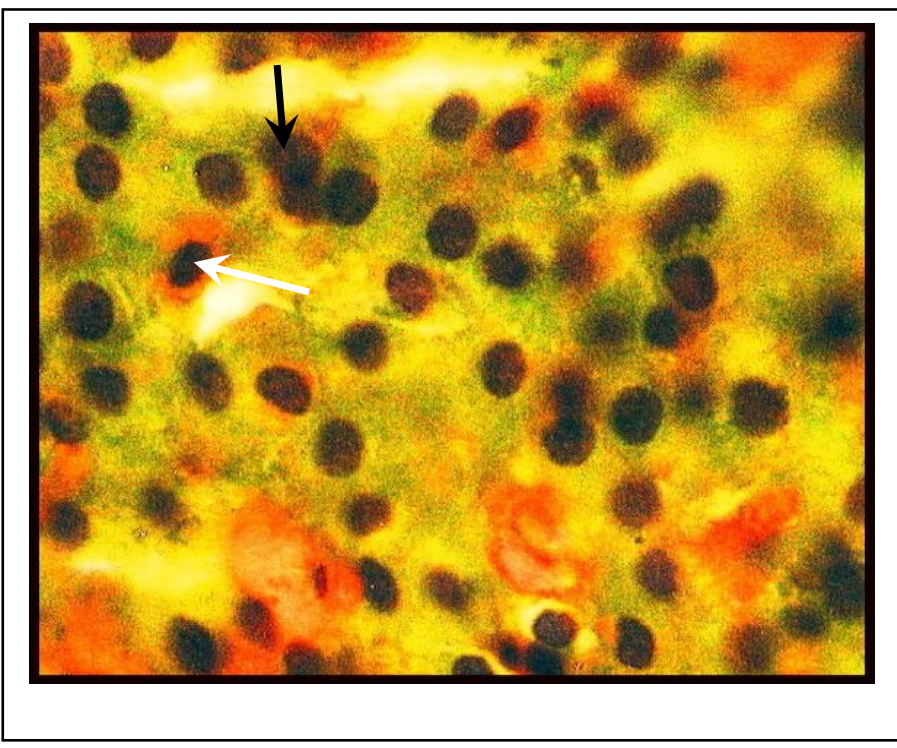

(Fig. 4) Photomicrograph of a control pancreas of adult albino rat showing the normal cellular distribution in the islet of Langerhans , the white arrow shows alpha cell, while the black arrow the beta cell . (Modified aldehyde fuchsin. stain X 1400) 


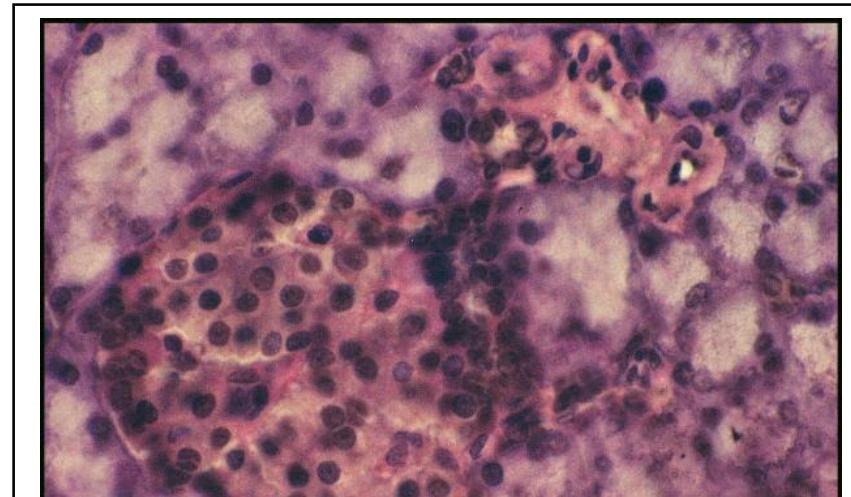

(Fig.5) Photomicrograph of a diabetic pancreas of adult albino rat showing the cellular distribution in islet of Langerhans, reduced islet size and poor differentiation of its cells. (Hx.\&E. stain X 1400)

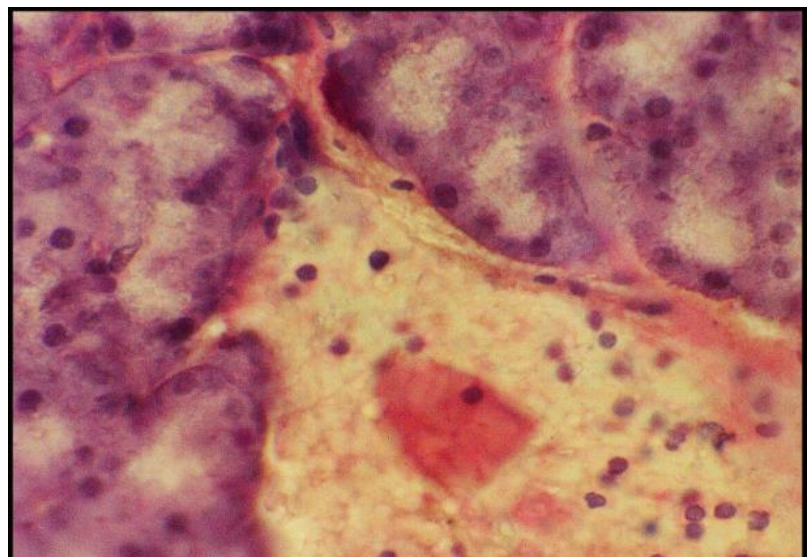

(Fig.7) Photomicrograph of a diabetic pancreas of adult albino rat showing marked degenerative changes in the islet and decreased islet cellularity. (Hx.\&E. stain X 1400)

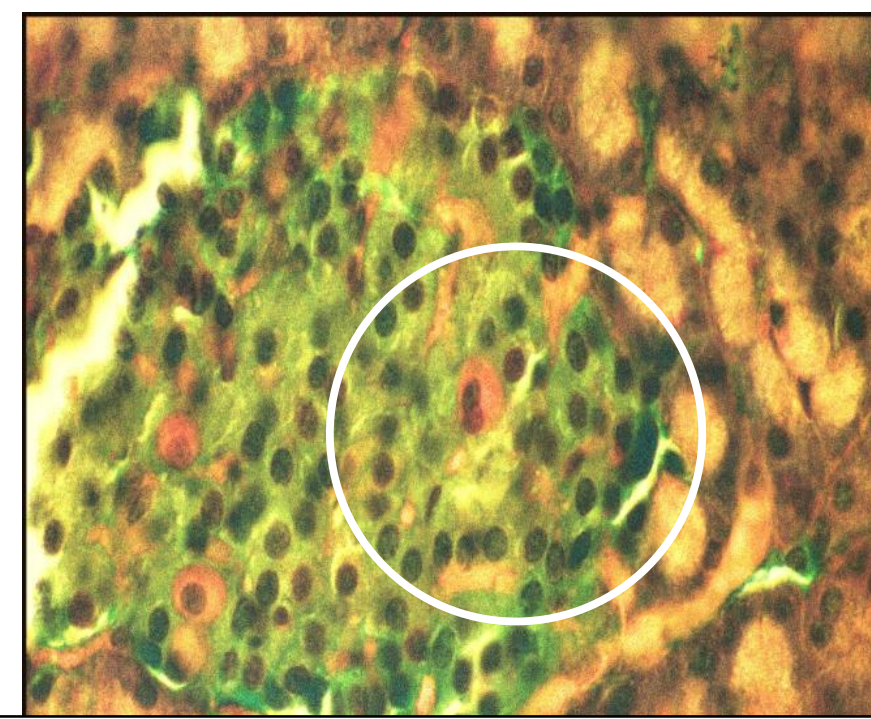

(Fig.9) Photomicrograph of a diabetic pancreas of adult albino rat showing cytoplasmic vacuolation, pyknosis and karyolysis of their nuclei (white circle). (Modified aldehyde fuchsin stain X 1100)

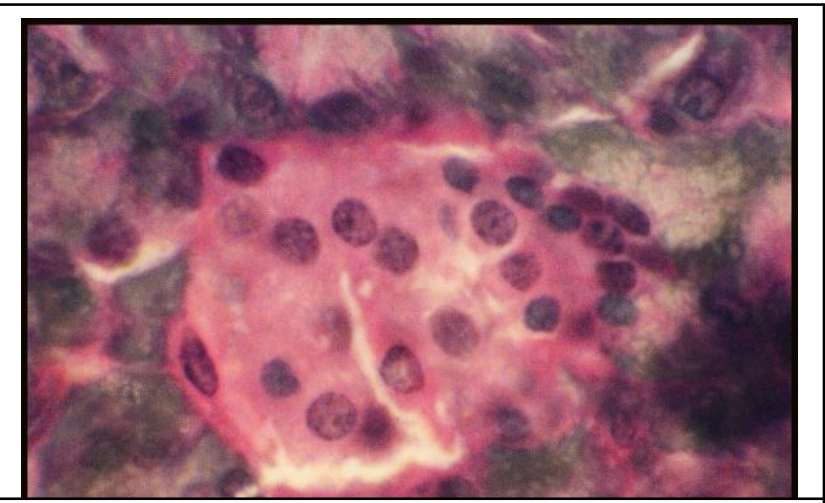

(Fig.6) Photomicrograph of a diabetic pancreas of adult albino rat showing marked reduction in the islet size and decreased islet celluarity. (Hx.\&E. stain X 1400)

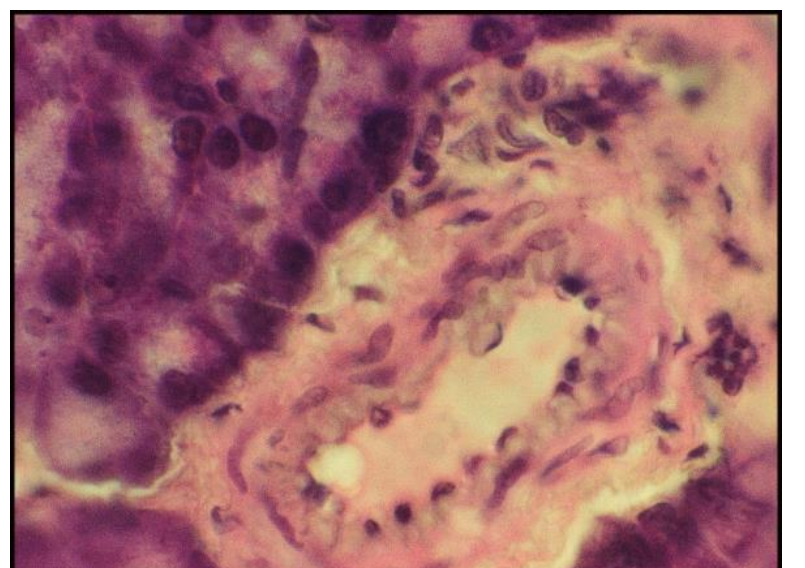

(Fig.8) Photomicrograph of a diabetic pancreas of adult albino rat showing marked degenerative changes in the artery suggesting arteritis. (Hx.\&E. stain X 1400)

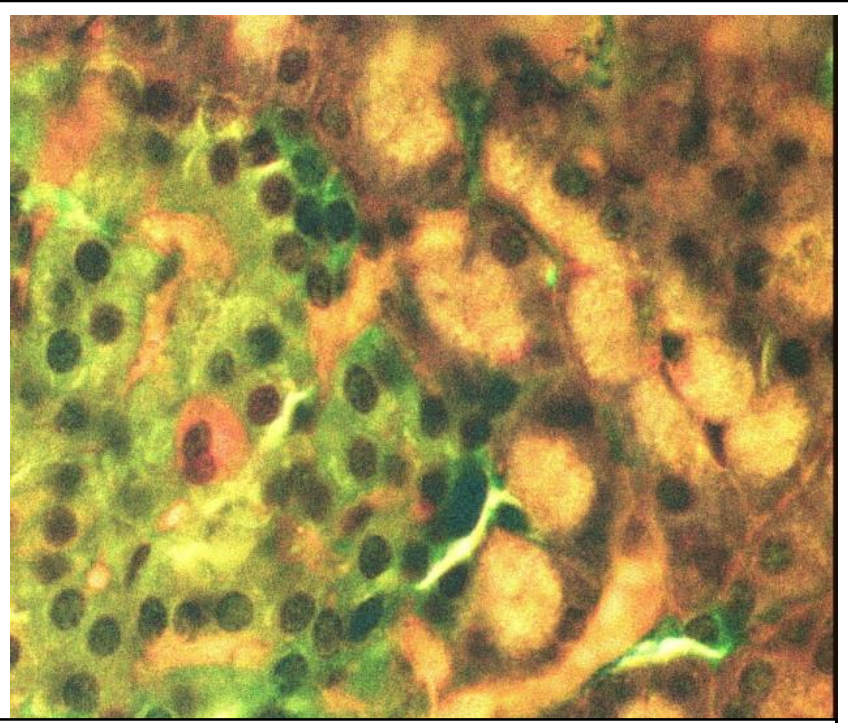

(Fig. 10) Photomicrograph of a diabetic pancreas of adult albino rat showing cytoplasmic vacuolation, pyknosis and karyolysis of their nuclei. (Modified aldehyde fuchsin stain X 1400) 


\section{Effect of Sitagliptin....}

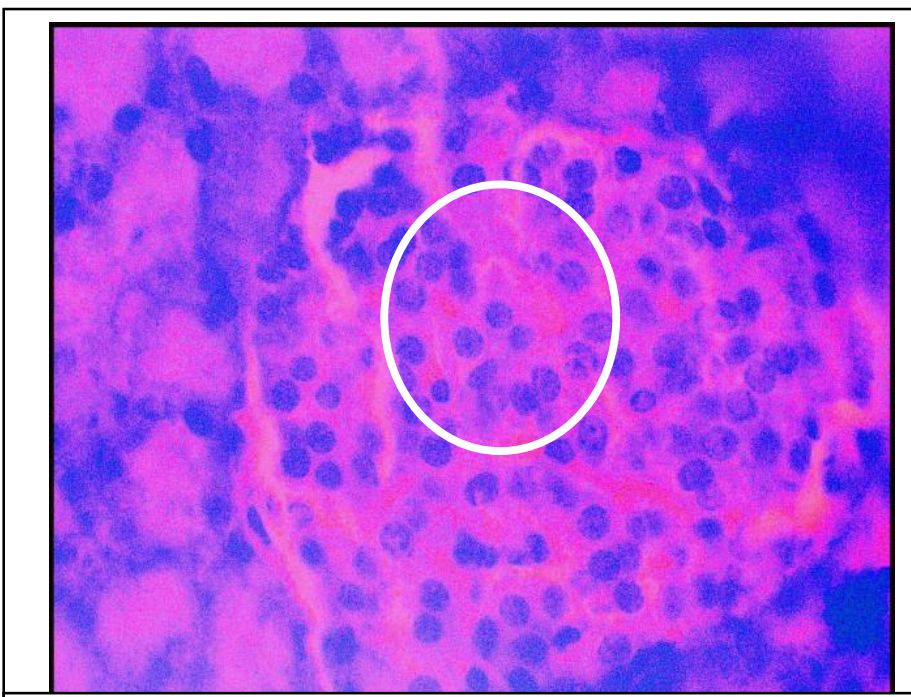

(Fig. 11) Photomicrograph of a diabetic pancreas of adult albino rat treated with sitagliptin showing the normal cellular distribution in the islet of Langerhans, There is increased cellularity with ill differentiation of the cell tvpes .(Hx.\&E. stain X 1100)

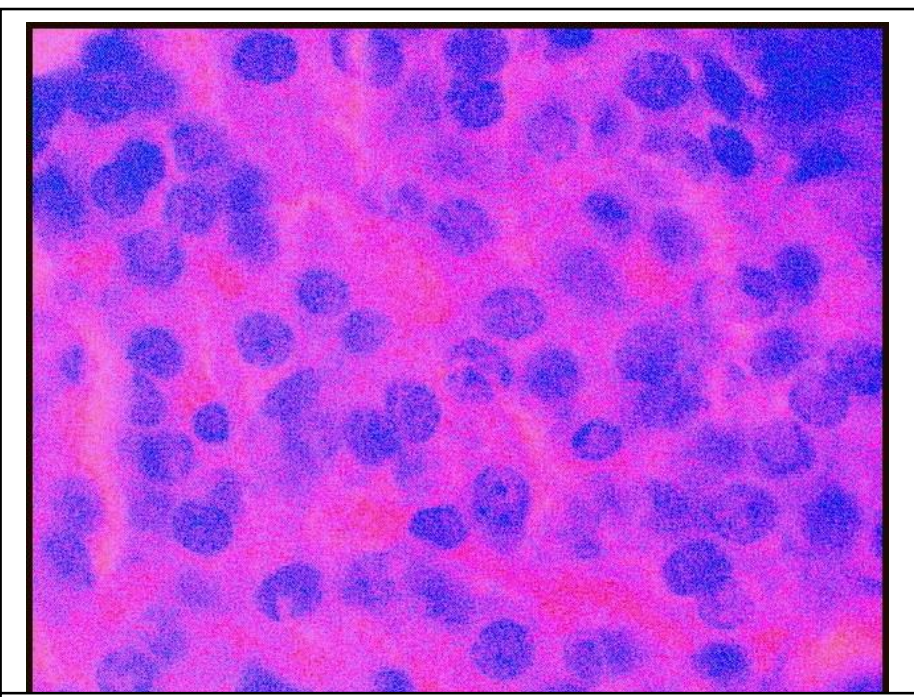

(Fig. 12) Photomicrograph of a diabetic pancreas of adult albino rat treated with sitagliptin showing partial return to the normal cellular distribution in the islet of Langerhans. (Hx.\&E. stain X 1400).

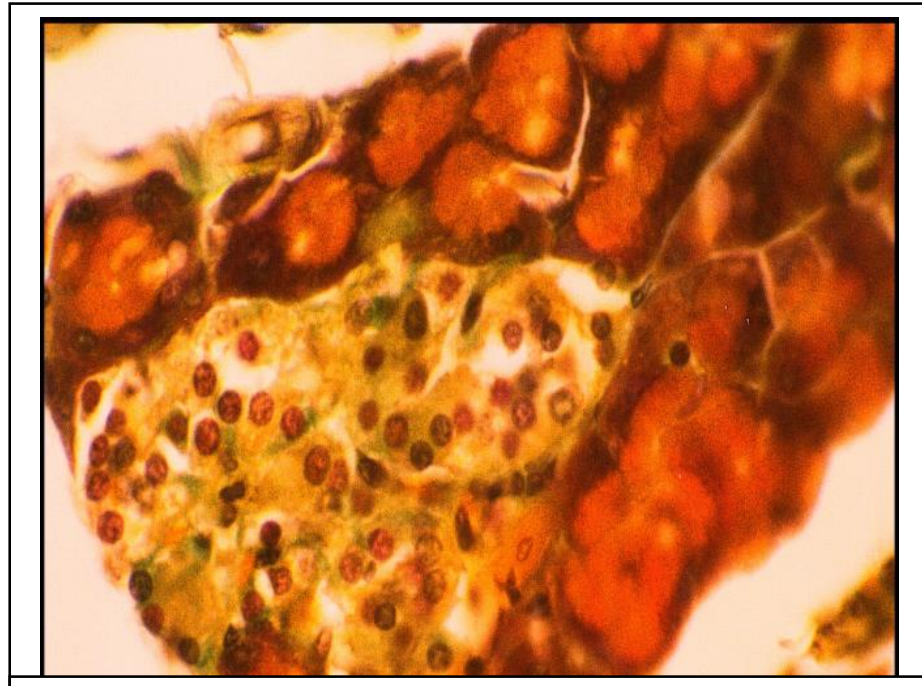

(Fig.13) Photomicrograph of a diabetic pancreas of adult albino albino rat treated with sitagliptin showing cellular distribution in the islet of Langerhans. (Modified aldehyde fuchsin stain X 1100)

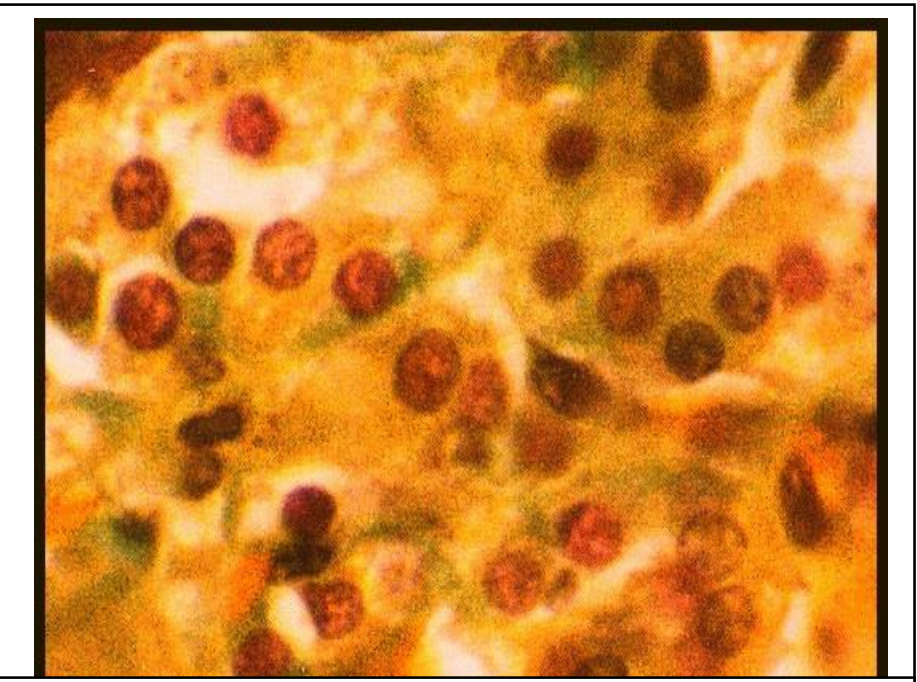

(Fig.14) Photomicrograph of a diabetic pancreas of adult albino rat treated with sitagliptin showing return of cellular distribution in the islet of Langerhans, the cells are poorly differentiated. (Modified aldehyde fuchsin stain X 1400) 
(Table 1)- Changes in the mean values of blood glucose level, serum insulin level, and HOMA in the different studied groups.

\begin{tabular}{|c|c|c|c|c|}
\hline Parameters & & Control & Diab. & Treatment \\
\hline \multirow{3}{*}{$\begin{array}{c}\text { Glucose } \\
\text { Mg/dl }\end{array}$} & $\mathbf{M} \pm \mathbf{S E}$ & $120 \pm 0.84$ & $255.4 \pm 6.48$ & $91.4 \pm 7.12$ \\
\hline & $\mathbf{P}_{1}$ & -- & $<0.01$ & $<0.05$ \\
\hline & $\mathbf{P}_{2}$ & -- & --- & $<0.01$ \\
\hline \multirow{3}{*}{$\begin{array}{c}\text { Insulin } \\
(\mathbf{u} / \mathbf{m l})\end{array}$} & $\mathrm{M} \pm \mathrm{SE}$ & $30.06 \pm 1.96$ & $13.46 \pm 0.39$ & $22.06 \pm 0.13$ \\
\hline & $\mathbf{P}_{1}$ & -- & $<0.01$ & $<0.05$ \\
\hline & $\mathbf{P}_{2}$ & -- & --- & $<0.01$ \\
\hline \multirow{3}{*}{ Homa-IR } & $\mathrm{M} \pm \mathrm{SE}$ & $33.84 \pm 2.37$ & $50.2 \pm 1.8$ & $7.97 \pm 0.45$ \\
\hline & $\mathbf{P}_{1}$ & --- & $<0.01$ & $<0.01$ \\
\hline & $\mathbf{P}_{2}$ & -- & -- & $<0.01$ \\
\hline
\end{tabular}

$P_{1}$ : in comparison with the control group; $P_{2}:$ in comparison with the diabetic groups.

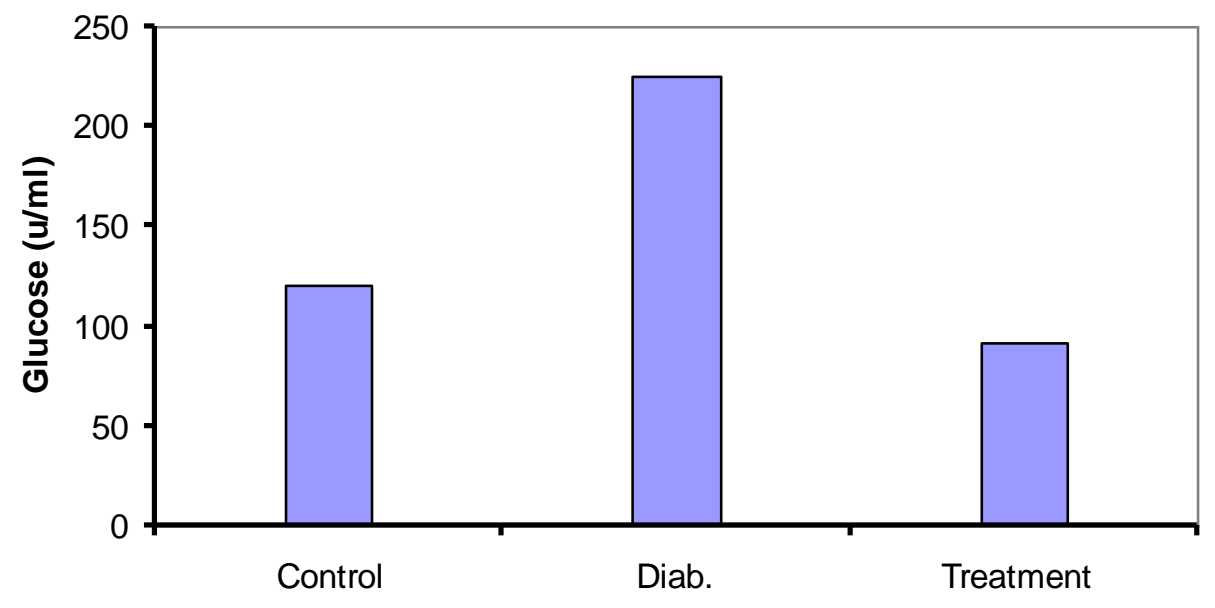

(Histogram.1)-Histogram showing serum blood glucose in the different groups of this study.

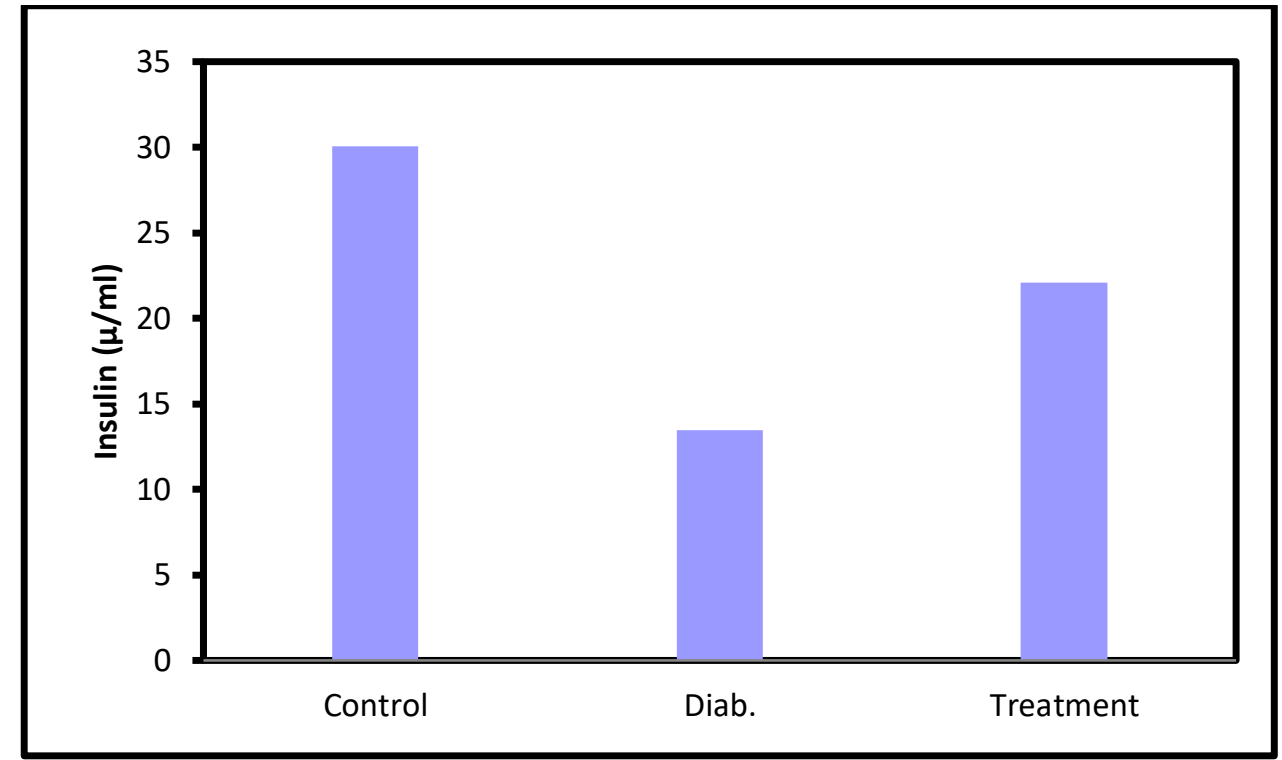


(Histogram.2)- Histogram showing insulin level in the different groups of this study.

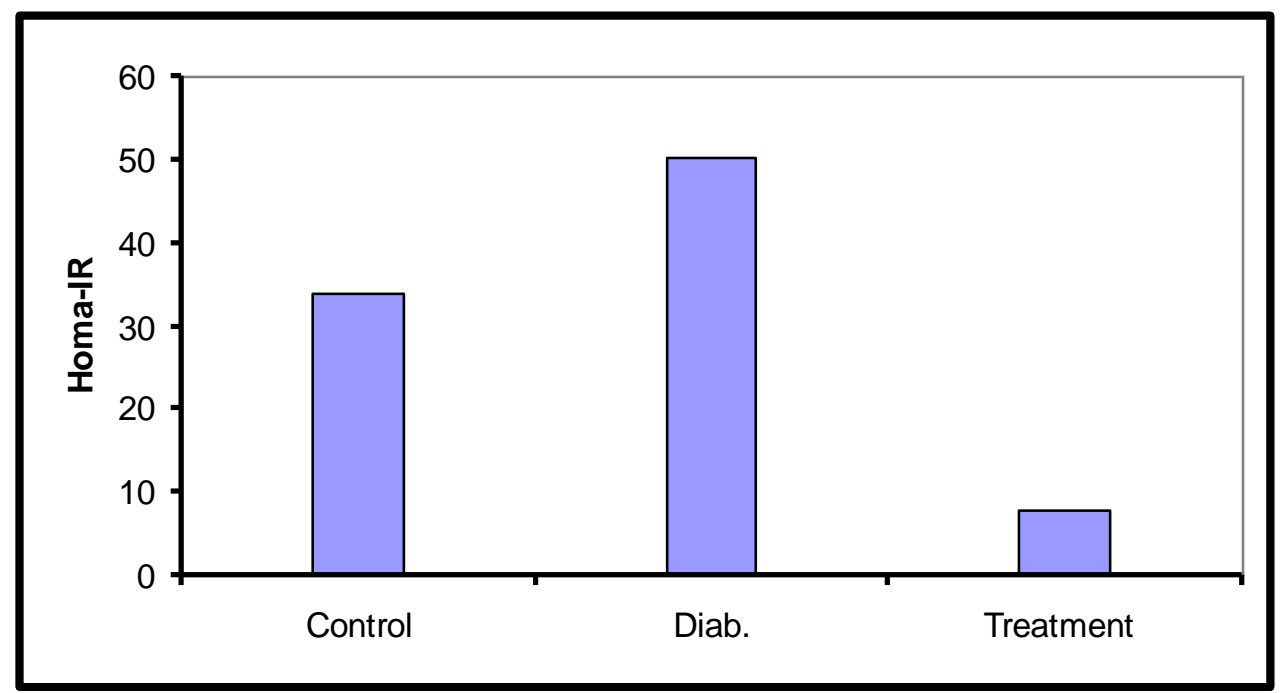

(Histogram.3)- Histogram showing HOMA in the different groups of this study.

\section{Discussion:}

Type II Diabetes is characterized by progressive deterioration in functions of the beta cells as it is usually associated with $50 \%$ loss of the beta cells mass and $60 \%$ necropsy at the time of diagnosis (Lebovitz, 2002). This decline in the beta cell mass is suggested to be due to accelerated apoptosis and is motivated by glucotoxicity, lipotoxicity, proinflammatory cytokines, leptin and islet cells amyloid (Wajchenberg, 2007). Using drugs such as incretin mimetics or enhancers has demonstrated antiapoptotic effect with clinical evidence of their beneficial effect on the human beta cell function (Wajchenberg, 2007).

Incretin hormones are released from the digestive tract in response to food intake and these hormones enhance glucose dependant insulin secretion from the pancreas, maintain glucose homeostasis through slowing of gastric emptying, inhibit glucagon secretion and increase satiety. Of the two major incretins, glucagon-like peptide
(GLP-1) and glucose-dependant insulinotropic polypeptide (GIP), only GLP-1 or its or enhancers (mimetics) have an effect on beta cell function (Drucker, 2006).

Several GLP 1 analogues known as "incretin mimetics" have been developed and are available as injectable forms (e.g. Exenatide and Liraglutide) or oral forms (e.g.Sitagliptin and Vildaglipin). Sitagliptin exert its effect through the inhibition of an active enzyme dipeptidyl peptidase 4 (DPP4), thus it prevent the rapid inactivation of GLP1 active forms (Chia and Egan 2008). They added that, similar to GLP-1, DPP4 inhibitors increase glucose insulin mediated secretion and suppress glucagon secretion (Chia and Egan 2008). This study examined the influence of sitagliptin "DPP-4 inhibitor" over 3 weeks period on glucose tolerance, insulin secretion and islet morphology in normal and type II diabetic rats. 
To do this study, induction of type II diabetes has been done via using alloxan. Alloxan was used to induce diabetes for two reasons; firstly, alloxan has a selective cytotoxic effect on beta cells (Okamoto 1984; Dunn et al., 1943). Secondly, alloxan injection leads to partial destruction of beta cells of the islets of Langerhans as it is rapidly uptaken by beta cells and has a direct effect on its cell permeability (Shafrir, 2003). For these reasons, alloxan is the drug of choice to experimentally induce type II diabetes in animal models.

In this study, islets of Langerhans in group II "control diabetic group" showed marked reduction of the islets size, poor differentiation of its cells, and decreased islets' cellularity. In parallel, these cellular changes were associated with marked degenerative changes in the vessels in the islets region suggesting arteritis. These results are supported with the previous studies that refer to glucotoxicity, lipotoxicity, and proinflammatory cytokines as possible motivators for exaggerated cellular apoptosis and inflammatory changes of the islets of Langerhans (Wajchenberg, 2007).

In this study, beta cells showed marked degenerative changes such as nuclear pyknosis, karyolysis, and cytoplasmic vacuolation. These degenerative changes were associated with marked hyperglycemia and hypoinsulinemia. According to Bolaffi $\boldsymbol{e t}$ al(1986) and Kessler et al(1999), these degenerative changes are usually associated with abnormalities in islets functions with subsequent hyperglycemia and hypoinsulinemia. Moreover, beta cell mass in the diabetic group II had been shown to be reduced in size with poor differentiation of its cells in comparison to group I "control group". These size reduction and poor differentiation may be attributable to the induced beta cells apoptosis. This beta cell apoptosis had been also noticed at autopsy and in isolated islets from diabetes type II patients (Huang et al., 2007; Laybutt et al., 2007).

When diabetic rats were treated by sitagliptin in "Group III", partial recovery of the islets of Langerhans to the normal cellular distribution and increased cellularity of islets with mild increase in beta cells number has been detected. These changes were associated with mild improving in both blood glucose and insulin profiles. Mu et al(2009)and Verspohl (2009) in their studies reported similar findings in reducing glucose level, reducing HBA1c level and improving insulin reduction. Sitagliptin is probably doing its effects via increasing GLP-1 concentration. GLP-1 had been shown to reverse loss of beta cell mass in human and animal models of diabetes via increasing new beta cell formation and decreasing $\beta$-cell apoptosis (Buteau et al., 2001; Deacon \&Holst 2002; Hui et al., 2003; Xu et al., 2006; Aschner et al., 2006; Raz et al., 2006; Poitout and Robertson2008). These sitagliptin benefits on beta cell mass and function may have been mediated by either its direct effects on beta cells or indirect by its action to lower blood 
glucose. Hyperglycemia can contribute to both reducing beta cell mass, increasing beta cell apoptosis and loss of beta cell function. Poor differentiation of beta cells that was detected in this study results after sitagliptin treatment may be due to the short term treatment (21 days) may not give enough time for beta cells to be fully differentiated. In summary, sitagliptin had synergistic effects on preserving B-cell mass in the rat model of type II diabetes and is able to improve glucose intolerance via increasing beta cells replication and improving islet functions.

\section{References:}

Ahren B, Schmitz O (2004): GLP-1 receptor agonists and DPP-4 inhibitors in the treatment of type 2 diabetes. Horm. Metab. Res., 36:867-876.

Ahren B, Landin-Olsson M, Jansson PA, Svensson M, Holmes D and Schweizer A (2004a): Inhibition of dipeptidyl peptidase-4 reduces glycemia, sustains insulin levels, and reduces glucagon levels in type 2 diabetes. J. Clin. Endocrinol. Metab., 89:2078-2084.

Ahren B, Gomis R, Standl E, Mills D and Schweizer A (2004b): Twelve- and 52-week efficacy of the dipeptidyl peptidase IV inhibitor LAF237 in metformin-treated patients with type 2 diabetes. Diabetes Care, 27:2874-2880.

Ahren B, Simonsson E, Larsson H, LandinOlsson M, Torgeirsson H, Jansson PA, Sandqvist M, Bavenholm $P$, Efendic S, Eriksson JW, Dickinson and, Holmes D (2002): Inhibition of dipeptidyl peptidase IV improves metabolic control over a 4-week study period in type 2 diabetes. Diabetes Care, 25:869-875.

Ahren B, Holst JJ, Martensson $H$ and Balkan B (2000): Improved glucose tolerance and insulin secretion by inhibition of dipeptidyl peptidase IV in mice. Eur. J. Pharmacol., 404:239-245.

Aschner P, Kipnes MS, Lunceford JK, Sanchez $M$, Mickel C and Williams-Herman DE (2006): Sitagliptin Study 021 Group. Effect of the Dipeptidyl peptidase-4 inhibitor sitagliptin as monotherapy on glycemic control in patients with type 2 diabetes. Diabetes Care, 29:2632-2637.

Brian D, Peter R. and Clifford J. (2006): Dipeptidyl peptidase IV (DPP IV ) Inhibitors: a newly emerging drug class for the treatment of type 2 diabetes.Diabetes Vasc. Dis. Res., 3:15965.

Buteau J, Foisy S, Rhodes CJ, Carpenter L, Biden TJand Prentki M (2001): Protein kinase
Czeta activation mediates glucagon-like peptide1-induced pancreatic beta-cell proliferation. Diabetes, 50: 2237- 2243.

Biankin AVand Biden TJ (2007): Endoplasmic reticulum stress contributes to beta cell apoptosis in type 2 diabetes. Diabetologia, 50: 752- 763.

Bolaffi JL, Nowlain RE, Grunz $L$ and Grodsky GM( 1986): Progressive damage of cultured pancreati islets after single early exposure to streptozotocin. Diabetes, 35:1027-1033.

Chia CW and Egan JM (2008): Incretin -based therapies in type 2 diabetes mellitus. J. Clin. Endocrinol. Metab., 93:3703-3716.

Clayden E C( 1971): Practical Section and Staining Churchill living stone; Edin. Burgh and London.

Deacon CFand Holst JJ(2002): Dipeptidyl peptidase IV inhibition as an approach to the treatment and prevention of type 2 diabetes: a historical perspective. Biochem. Biophys. Res. Commun., 294: 1- 4.

Drucker DJ (2006): Incretin-based therapies: a clinical need filled by unique metabolic effects. Diabetes Educ., 32:65-71.

Dunn J S, Sheehan HL and Moletchie N G B(1943): Necrosis of islets of Longerhans. Lancet L: 484- 487. Deacon, C.F, Holst, J.J. 2002: Dipeptidyl peptidase IV inhibition as an approach to the treatment and prevention of type 2 diabetes: a historical perspective. Biochem. Bophys. Res. Commun., 294: 1-4.

Eiji K(2011): Sitagliptin is effective and safe as add- on to insulin in patients with absoluteInsulin deficiency : a case series.Journal of Medical case Reporte., 5:117 doi:10.

Halami NS (1962): Stain Technol., 27 pp 184 carlton's histological techniques, drury and wallington, R.A.B.A (1967).

Halimi S (2008); DPP-4 inhibitors and GLP-1 analogues: for whom? Which place for incretins in the management of type 2 diabetic patients? Diabetes Metab .34 Suppl., 2: 91-95.

Herman GA, Stevens C, Van Dyck K, Bergman A, Yi B, De Smet M, Snyder K, Hilliard D, Tanen M, Tanaka W, Wang AQ, Chen L, Zeng W, Musson D, Laethem M, Zhou YY, Winchell G, Davies MJ, Ramael S, Gottesdiener KM, Wagner JA (2005): Pharmacokinetics and pharmacodynamics of single doses of sitagliptin, an inhibitor of dipeptidyl peptidase-IV, in healthy subjects. Clin. Pharm. Ther .,78:675-688.

Holst JJ, Gromada J (2004): Role of incretin hormones in the regulation of insulin secretion in diabetic and nondiabetic humans. Am. J. Physiol .Endocrinol. Metab., 287:E199-E206.

Huang CJ, Lin CY, Haataja L, Gurlo T, Butler AE Rizza RA and Butler PC (2007): High expression rates of human islet amyloid polypeptide induce endoplasmic reticulum stress mediated beta-cell apoptosis, a characteristic of 
humans with type 2 but not type 1 diabetes. Diabetes, 56: 2016- 2027.

Hui H, Nourparvar A, Zhao X and Perfetti R. (2003): Glucagon-like peptide-1 inhibits apoptosis of insulin-secreting cells via a cyclic 5'-adenosine monophosphate-dependent protein kinase A- and a phosphatidylinositol 3-kinase-dependent pathway. Endocrinology 144: 1444- 1455.

Kessler J, Hehmke B ,Kloting I and Kohnert KD (1999): Relatioship between the hisopatho$\operatorname{logy}$ of the endocrine-exocrine pancreas parenchyma and beta-cell function in the Chinese hamster CHIG / Han subline. Pancreas 19(1): 8997.

Kim D, Wang L, Beconi M, Eiermann GJ, Fisher MH, He H, Hickey GJ, Kowalchick JE, Leiting B, Lyons K, Marsilio F, McCann ME, Patel RA, Petrov A, Scapin G, Patel SB, Roy RS, Wu JK, Wyvratt MJ, Zhang BB, Zhu L, Thornberry NA and Weber AE (2005) (2R)-4oxo-4-[3-(trifluoromethyl)-5,6-

dihydro[1,2,4]triazolo[4,3-a]pyrazin-7(8H)-yl]1-

(2,4,5-trifluorophenyl)butan-2-amine: a potent, orally active dipeptidyl peptidase IV inhibitor for the treatment of type 2 diabetes. J. Med. Chem. 48:141-151.

Laybutt DR, Preston AM, Akerfeldt, MC, Kench JG, Busch AK, Biankin AV and Biden, TJ. (2007): Endoplasmic reticulum stress contributes to beta cell apoptosis in type 2 diabetes Diabetologia, 50(4):752-63.

Lebovitz HE. 2002 Type 2 diabetes: how far have we come? British. J. Diab. \& Vasc .Dis. 2(6):446-49.

Malaisse WJ(1982): Alloxan toxicity to the pancreatic B- cell . A new hypothesis. . Biochem.. Pharmacol., 31: 3527-3537.

Mest HJ, Mentlein R (2005): Dipeptidyl peptidase inhibitors as new drugs for the treatment of type 2 diabetes. Diabetologia 48:616-620.

Mu j, PetrovA and PetrovA(2009): "Inhibition of DPP-4 with sitagliptin improves glycemic control and restores islet cell mass and function in a rodent model of type 2 diabetes," European Journal of Pharmacology, vol. 623, no. 1-3, pp. $148-154$.

Okamoto H (1984): Molecular basis of experimental diabetes: Degeneration, oncogensis and regeneration of pancreatic B - cells of islets of Langerhans. Bio. Essays., 2: 15- 21.

Raz Im Hanefeld M, Xu L, Caria C, WilliamsHerman Dand Khatami H( 2006): Efficacy and safety of the dipeptidyl peptidase-4 inhibitor sitagliptin as monotherapy in patients with type 2 diabetes mellitus. Diabetologia, 49: 2564- 2571.

Reeves, W.G. (1983) Insulin antibody determination : Theoretical and practical consideration Diabetologia 24: 339- 403.

Reimer MK, Holst JJand Ahren B (2002): Long-term inhibition of dipeptidyl peptidase IV improves glucose tolerance and preserves islet function in mice. Eur J Endocrinol 146:717-727.

Paget GE and Barnes JM(1964): Evaluation of drug activities pharmacometrics. $1^{\text {st }}$ ed. Laurence, D. R. and Bacharach, A. L, Academic press, London and New York.

Poitout V and Robertson $\operatorname{RP}(2008)$ : Glucolipotoxicity: fuel excess and beta-cell dysfunction. Endocr. Rev., 29: 351- 366.

Pospisilik JA, Stafford SG, Demuth HU, Brownsey R, Parkhouse W, Finegood DT, McIntosh CH and Pederson RA (2002) Longterm treatment with the dipeptidyl peptidase IV inhibitor P32/98 causes sustained improvements in glucose tolerance, insulin sensitivity, hyperinsulinemia, and $\beta$-cell glucose responsiveness in VDF (fa/fa) Zucker rats. Diabetes, 51:943-950.

Shafrir E( 2003): Diabetes in animals contribution to the unders standing of diabetes by study of its etiopatheology, in animal models Bioennial review. Smith- Garden, $\mathrm{p}_{\mathrm{p}}$ 231- 235.

Trinder P(1984); Determination of blood glucose using 4- aminophenazone. J. clin. Path., 22; $246-$ 252.

UK Prospective Diabetes Study (UKPDS) Group(1998): Intensive blood glucose control with sulfonylureas or insulin compared with conventional treatment and risk of complications in patients with type 2 diabetes. UKPDS 33 Lancet., 352: 837-853.

Wajchenberg BL (2007): Beta cell failure in diabetes and preservation by clinical treatment. Endocr. Rev., 28:187-218.

Xu G, Kaneto H, Lopez-Avalos MD, Weirw GCand Bonner-Weir S (2006): GLP-1/exendin-4 facilitates beta-cell neogenesis in rat and human pancreatic ducts. Diabetes Res. Clin. Pract.; 73: $107-110$.

VerspohIEJ. (2009):"Novel therapeutics for type 2 diabetes: incretin hormone mimetics (glucagonlike peptide-1 receptor agonists) and dipeptidyl peptidase-4 inhibitors," Pharmacology and Therapeutics, vol. 124, no. 1, pp. 113-138. 
تأثير عقار السيتاجليبتين على بنكرياس الجرذان البيضاء البالغة فى حالات مرض السكر التجريبى (دراسة ميكروسكوبية وكيمياء حيوية)

تامر مسعد محمود ابو عمارة و زينب محمود جبالى حيوبة

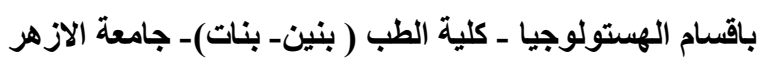

المقدمة و الهـف من الدراسة :

يعنبر مرض السكر من المشاكل الكبرى التى تؤثر على عدد كبير من المرضى فى جميع أنحاء العالم وقد أجريت هذه الاراسـة

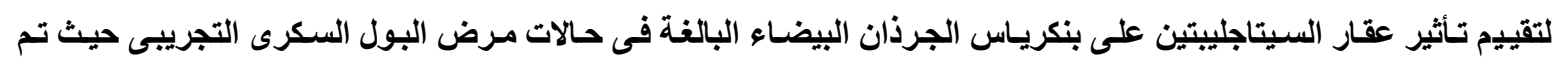

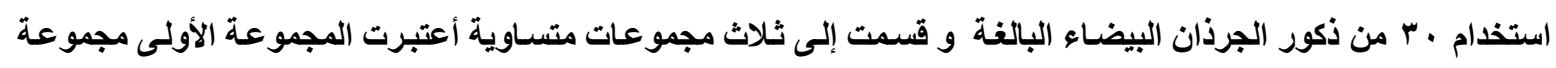

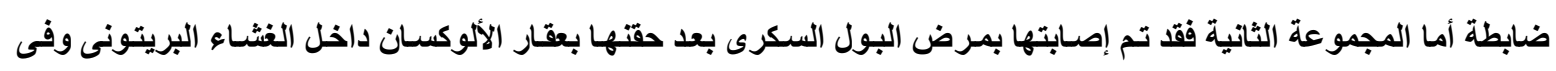

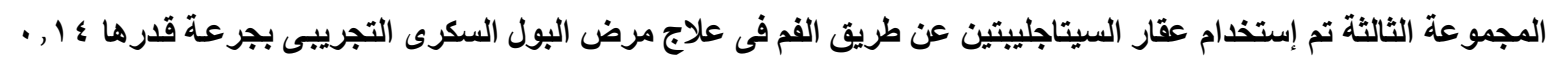

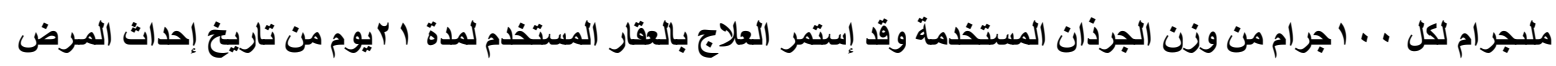

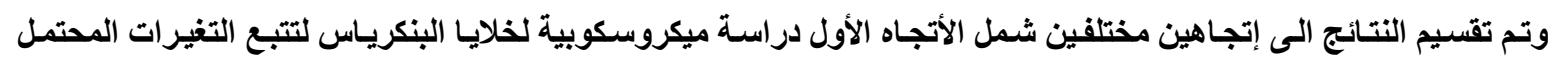

حدوثها فى المجموعات المختلفة بعد صبغها باستخدام صبغات الهيماتوكسيلين والايوسين وصبغة الدهيد فوكسين المعدلة. أما الاتجاه الثانى فهو عبارة عن تحليل معملى لتقيم كمى لنسبة السكر والأنسولين فى اللدم والتى تظهر مدى كفاءة البنكرياس فى المجموعات المختلفة .

النتائج

أحلث مرض السكر أنحلال في عدد من خلايا بيتا في شكل تجويفات فى سيتوبلازم الخلايـا و تغير فى شكل النواة مـع وجود

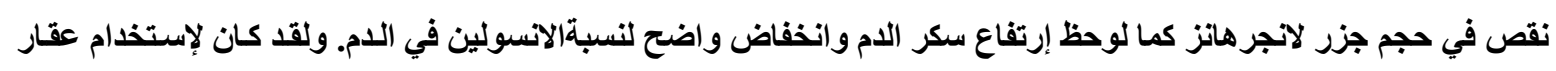

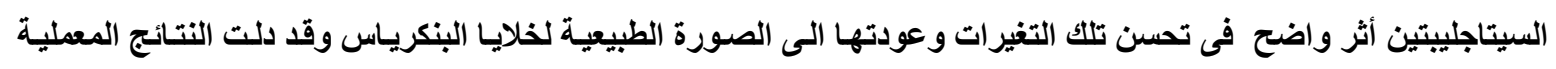

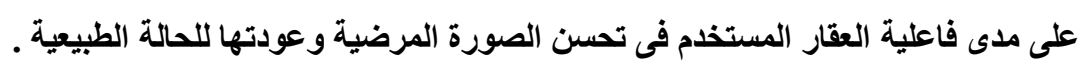

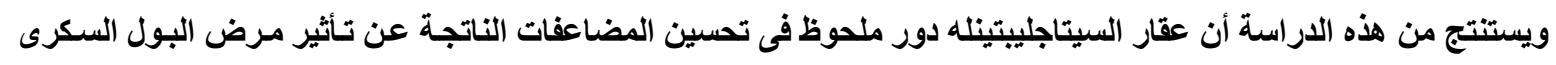
على خلايا البنكرياس. 